\title{
Still hopes for reversal of US decision
}

Washington

THE United States may after all stay in the United Nations Educational, Scientific and Cultural Organization (Unesco) after the end of the year, when it has said it will leave unless major changes are made in the agency's management and ideology. Congress, which was not consulted by the State Department before the US withdrawal was announced last December, has begun to take a lively interest in Unesco. Congressional accountants will shortly arrive in Paris to take up an offer to look at the agency's books. And Assistant Secretary of State Gregory Newell admitted last week that it would "intellectually dishonest" to declare the US decision final until its delegation actually leaves Unesco on 31 December.

The State Department has reluctantly promised to give Congress whatever help it needs, but it does not expect the congressional inquiry to find important new information. Mr Newell said the review already conducted by the executive branch had been extensive; 13 government agencies and departments and $\mathbf{8 3}$ overseas embassies had taken part. The congressional initiative, led by New York Democrat James Scheuer, will be a comparatively modest affair restricted to an examination of financial management procedures.

Yet the congressional investigation, coupled with the start of hearings last week by the House of Representatives Committee on Science and Technology, has encouraged speculation that the US pull-out may yet be averted. The renewed debate has also encouraged the State Department to reveal more findings of its own review.

This newly-released information confirms that the decision to withdraw was taken despite unambiguous warnings from the US scientific community that the weight of tangible benefits "clearly justified" continued membership. A survey conducted for the State Department by the National Science Foundation (NSF) concluded that Unesco gives US scientists valuable access to research resources and data, enables the United States to share the costs of large international projects and provides contact with scientists with whom Americans might not otherwise work.

The NSF survey also acknowledged that the agency is imperfect, that its scientific effort is too diffuse, that administrative costs are high and that the quality of scientific staff recruited from developing countries is often poor. But it suggested that the United States itself is at least partly to blame. The absence of a central body to coordinate US participation has made it difficult to persuade eminent scientists to join
Unesco projects. And the effectiveness of the US Mission in Paris has been impaired by cuts in its staff and budget.

The specific benefits of continued membership, pinpointed in NSF's submission to the State Department, included: - Participation in a government-level body to attack problems of global significance such as the ecological research conducted through the Man in the Biosphere (MAB) programme, the geological research of the International Geological Correlation Programme (IGCP) and earthquake research conducted by the Natural Hazards Programme (NHP).

- Access to research data, particularly marine data.

- Cost-sharing and access to international facilities, such as the International Centre for Theoretical Physics at Trieste.

- Opportunities to work with scientists from countries with which the United States otherwise has little contact.

Withdrawal from Unesco, the report concluded, would weaken the United States' scientific leadership in the world and contribute to the further politicization of the agency. The State Department's minimum conditions for reviewing its decision to leave, according to $\mathrm{Mr}$ Newell, are an end to what the State Department regards as an already intolerable degree of politicization, a budget freeze and abandonment of the agency's controversial new world information and communications order. He said the United States does not expect those changes to occur.

Congressional officials complain privately that the State Department does not really want the agency to reform itself because the Reagan Administration sees withdrawal from Unesco as a useful warning to the United Nations as a whole. Congress, on the other hand, genuinely wants to see Unesco mend its ways, but believes the removal of its director general, $\mathrm{Mr}$ Amadou-Mahtar M'Bow, must be achieved first. The State Department, in contrast, stresses that it has no personal quarrel with Mr M'Bow, except for his recruitment to the secretariat of individuals "who have served him poorly". Meanwhile, it is embarking on a vigorous diplomatic campaign to explain its reasons for leaving.

The department claims that in consultations with 115 countries which are members of Unesco there has so far been "nearunanimous" agreement with the findings of the United States' review of Unesco, and some 15 countries are now said to be undertaking similar reviews. The meetings are ostensibly designed to explain its decision to foreign countries and to ensure that the United States' final year in Unesco is a productive one. But they serve equally well to keep the agency guessing about what the United States really intends to do at the end of the year.

Peter David

Los Angeles reactor

\section{Planned scramble for Olympics}

\section{Los Angeles}

B. 11 IN i to pressure from state politicians, the University of California at Los Angeles (UCLA) last week agreed to shutdown its research nuclear reactor during the Olympic Games to guard against the possibility that terrorists might attack the facility. UCLA will also erect concrete barriers around the building housing the 100-kilowatt reactor and post 24-hour security guards outside.

The measures were requested last month by state Assemblymen Gray Davis and Mike Roos, both of whom represent communities surrounding the university. "There are a number of eminent scientists who feel the reactor poses a threat to the community and is an inviting target to terrorists", Mr Davis said. Local citizens fear the highly enriched uranium could be stolen and made into a bomb or that the fuel could somehow be dispersed.

The university is cooperating with the demands but feels the dangers are greatly exaggerated. According to Walter Wegst, UCI.A's director of research and occupational safety, the reactor is completely surrounded by tons of concrete and slabs of graphite. "Even if you got into the facili- ty", he said, "it would take a day or more, maybe two days, to reach the fuel." The Argonaut-type reactor is is housed on the ground floor of an eight-storey building. Any explosion large enough to damage the reactor would destroy the entire building, $\mathrm{Mr}$ Wegst said, causing it to collapse on the reactor, sealing in the fuel and dangerous radioactive isotopes.

"We think the fuel would probably be more protected from the environment after the building collapsed on it that it is right now", Wegst said. To "play it very safe" and protect the people who work in the building, UCLA will go along with the extraordinary measures, a campus spokesman said.

The UCLA research reactor is still subject to relicensing hearings before the Nuclear Regulatory Commission which have been going on since 1980 . At issue is the question of whether small research reactors should use highly enriched uranium fuel - which could attract terrorists - or switch when feasible to low enriched uranium fuel. The conversion to low-grade fuel is under study at UCLA but the material is not commercially available.

Sandra Blakeslee 